Research, part of a Special Feature on Education and Differential Vulnerability to Natural Disasters

\title{
Vulnerability and the Role of Education in Environmentally Induced Migration in Mali and Senegal
}

\author{
Victoria van der Land ${ }^{1}$ and Diana Hummel ${ }^{1,2}$
}

\begin{abstract}
In the West African Sahel, the majority of the population depends on subsistence farming and livestock breeding and is thus particularly vulnerable to climatic changes. One possible response to natural hazards is migration. Recent research suggests that environmentally induced mobility is closely linked to the social vulnerability and adaptive capacity of individuals and groups. However, only little attention has been paid thus far to the role of formal education in this context. Our objective was to fill this gap by examining the role of formal education in environmentally induced migration as one characteristic of social vulnerability to environmental change. Our analysis focuses on two regions in the West African Sahel, Bandiagara in Mali and Linguère in Senegal, that are presumed to be particularly affected by climate change and environmental degradation. Our results reveal that formal education plays an important role in reducing vulnerability to environmental stress because people with a higher level of education are usually less dependent on environmentally sensitive economic activities such as farming. Moreover, an agricultural economic activity can be an obstacle to a high level of formal education. We found no significant effect of people's education on the migration experience as such. However, motives for migration differ considerably depending on the amount of education received, suggesting that migration constitutes a livelihood strategy, particularly for the lower educated.
\end{abstract}

Key Words: adaptive capacity; education; environmentally induced migration; livelihood strategies; Sahel; social vulnerability

\section{INTRODUCTION}

The impact of climate change and climate variability on human populations in the West African Sahel is a major global concern. Today, most people living in that region still depend on subsistence and small-scale farming or livestock breeding and are thus highly vulnerable to climatic and environmental changes. An extremely variable rate of rainfall plus land degradation caused by climatic changes and human activities make it particularly pressing for people to adopt adequate adaptation strategies (Cline 2007, Mertz et al. 2010, Samimi and Brandt 2012). Given these social-ecological conditions, migration constitutes a possible response and has been widely reported for regions in the West African Sahel (Findley 1994, Doevenspeck 2011, Scheffran et al. 2012). However, there is an increasing consensus within academic debate that environmentally induced migration is a multi-causal phenomenon. The decision to migrate is usually influenced not only by environmental drivers but also by cultural, economic, political, and social conditions. In each specific context, these interactions can increase or decrease migration (Black et al. 2011, Piguet et al. 2011, Renaud et al. 2011).

The concept of social vulnerability and the sustainable livelihoods approach (SLA; Chambers and Conway 1992, Carney 1998) represent useful analytical tools in analyzing the role of formal education in environmentally induced migration (McLeman and Smit 2006, McLeman and Hunter 2010, Tacoli 2011a). According to these concepts, social factors constitute a mediating function in the relation between environmental factors and migration. People have access to different assets such as natural resources, education, and skills, or to networks of social support. These assets can be translated into different livelihood strategies and they determine the capacity or incapacity of individuals and groups to subsist under conditions of stress. Social vulnerability thus refers to "the ability or inability of individuals and social groupings to respond to, in the sense of cope with, recover from or adapt to, any external stress placed on their livelihoods and wellbeing" (Kelly and Adger 2000:328). Migration then, both domestic and international, can be regarded either as a failure to adapt to environmental changes or as a strategy on the part of individuals and households to reduce their vulnerability to environmental and nonenvironmental stresses, or as a key component of livelihoods (Tacoli 2011b, Rademacher-Schulz and Mahama 2012, Scheffran et al. 2012).

Education is considered one of several indicators (e.g., socioeconomic status, sex/gender, ethnicity, age, occupation, family structure) that affect people's social vulnerability (Cutter et al. 2003). Yet there is little scientific knowledge so far about the role of education when it comes to people's vulnerability to environmental hazards and environmentally induced migration. Recent studies illustrate that people's education level may enhance their ability to cope with environmental disasters and stress (Wamsler et al. 2012, K.C. 2013), and Lutz and K.C. (2011) note that educational attainment is associated with different migration patterns. According to Adger et al. (2004:75), "education is strongly related to poverty and livelihoods; populations with overall low levels of education are likely to depend on climate- 
sensitive economic activities such as agriculture." Striessnig et al. (2013:5) revealed that education "is the single most important social and economic factor associated with a reduction in vulnerability to natural disasters." One of several reasons listed by the authors for reduced vulnerability to climate-change-related risks is that formal education results in higher income at the individual and household level. Furthermore, K.C. (2013:8) found that educated individuals in a household are likely to be involved in nontraditional occupations; this helps to diversify the household's income and makes the household better equipped to cope in times of disaster. A high standard of education for individuals, both men and women, is assumed not only to present greater opportunities for employment in the formal sector, but also to enhance their (autonomous) mobility, locally and internationally, so that they exhibit a higher propensity for migration (Adepoju 1995a, 2002, de Haas 2008).

Against such a backdrop, we aim to analyze the role of formal education in the context of social vulnerability in fragile environments, with a focus on migration. Our analysis is based on empirical research into the social-ecological conditions of population movements in two selected regions in the Sahelian countries Mali and Senegal (Hummel et al. 2012). The analysis starts from the premise that education is one characteristic of social vulnerability to environmental changes. We assume that people with a low level of education are more dependent on climate-sensitive economic activities such as agriculture and are thus generally more vulnerable to any type of hazard. This leads to our hypotheses that: (1) people with a high formal education are less vulnerable to environmental changes, and (2) a high level of education increases the propensity for (and hence probability of) migration for both men and women.

Drawing on the quantitative and qualitative data from the empirical study, we analyze the role of formal education in vulnerability to environmental stress in the light of other attributes such as gender, age, and ethnicity, and examine migration motives, coping strategies, and the environment sensitivity of people's economic activities.

\section{STUDY AREAS AND METHODS}

Our analysis is based on research conducted within the interdisciplinary research project "micle: migration, climate change, and environment" (http://www.micle-project.net). The micle project examines the interdependencies between climate and environmental change, with a focus on land degradation and migration in two study areas in the West African Sahel.

The West African Sahel experienced a substantial decrease in rainfall from the 1950s until at least the late 1980s, with severe droughts in the 1970s and 1980s. In addition, the Sahel has been identified as one of the regions that are particularly vulnerable to future climate change, with a major impact on human livelihoods (IPCC 2007).
The empirical research was carried out at two spatial levels: with villagers in two rural study areas in the West African Sahel, Bandiagara in Mali and Linguère in Senegal (Fig. 1); and with migrants originating from these two study areas but now living in the national capitals, Bamako and Dakar (chosen as examples for destinations of migration). The rural study areas were selected for several reasons. First, they suffer from highly variable precipitation and changes in vegetation and are considered likely to be affected by future droughts and land degradation. Second, subsistence and small-scale farming/livestock breeding are the main sources of income in both areas, which means that people are considered extremely vulnerable to environmental changes. Finally, both areas are characterized by high population dynamics with a negative net migration rate, meaning that more people are leaving than are entering the areas (Bocquier and Diarra 1999, ANSD 2006, Mbow et al. 2008).

Fig. 1. Location of the study areas in Linguère, Senegal, and in Bandiagara, Mali.

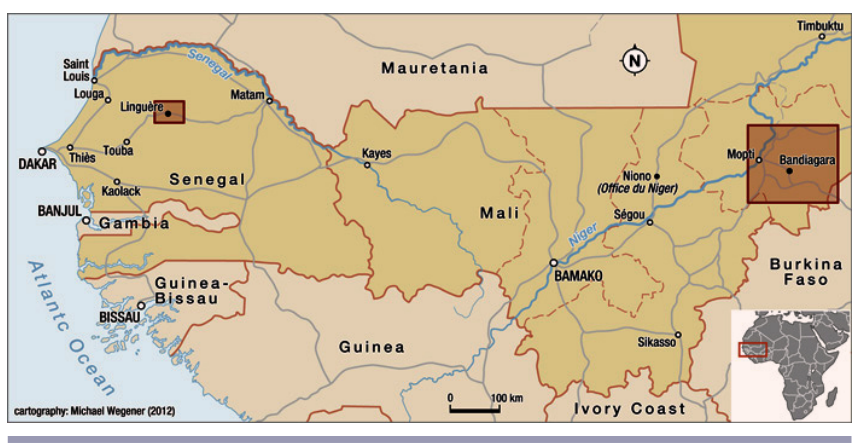

The empirical data collection was divided into two phases combining different qualitative and quantitative methods: an explorative phase from February to April 2011 and a main field phase from January to April 2012. The explorative phase included qualitative interviews and participant observation as applied methods in the two study regions and was designed to prepare for the main field work in 2012. During the main field work, a survey with 905 people was conducted with villagers in both rural study areas (661 questionnaires) and with migrants in the capitals (244 questionnaires). In addition, 60 qualitative interviews and eight group interviews, as well as participant observation, were conducted over several months in the two study areas and in the capitals. Interviews were conducted in French if possible, but more often in local languages with the assistance of translators.

Interviewees and survey participants in the villages were selected randomly; they differed in terms of age, education, ethnicity, gender, and migration experience. The survey was confined to people aged $\geq 18 \mathrm{yr}$, whereas the interviews were also conducted with younger people. The composition of 
ethnicities depended on the location of the rural study areas: in Senegal the survey and the interviews included the Wolof (traditionally farmers) and the sedentary Fulani or Peulh (traditionally nomadic livestock breeders); in Mali it was mainly the Dogon (traditional farmers) who participated in the study. In the two capitals, people from the rural study areas were identified by a mixed method of migrant tracking and snowball sampling (Urry 1999, Diekmann 2005).

In the standardized analysis, cross-tabulations were applied to identify relationships between different attributes/variables and to test our assumptions and hypotheses as described above. Statistical significance was tested by applying chi-square $\left(\chi^{2}\right)$ tests, with the significance level set at $P \leq 0.05$. For analyzing the role of formal education, three categories of education were used: "no formal education", which includes people classed as illiterate or as having a basic knowledge of reading and writing without any school attendance; "primary education"; and "high level of education", which includes secondary and university education. These three categories were the result of combining the two lowest and two highest of the original five categories for statistical purposes because very few people saw themselves in the categories "basic knowledge of reading and writing", either in a local or official language, and "university level". We combined "basic knowledge" with illiteracy into a "no formal education" category, rather than including it with "primary education", for several reasons: (1) the aim of the study was to analyze the impact of formal education, (2) tests showed that responses of this group were often more akin to the illiteracy group than the primary education group, and (3) this was a necessary step to control the social desirability that might have a distortive effect on the "basic knowledge" group (Roth and Heidenreich 1995). The social vulnerability of interviewees to environmental stress has been operationalized by the main economic activities of the survey participants and their families (and the environmental sensitivity of these activities) as well as by people's strategies for coping with bad harvests and bad conditions for pasture and by their migration motives. The survey participants were asked for the motives behind their initial and last migration.

The qualitative interviews were analyzed by applying a content analysis with different categories (Mayring 2007). The citations from the interviews in this study were translated from French into English by the authors. Here, the qualitative research aimed at gaining deeper understanding of the living conditions and customs in the villages, of people's motives for migration, and of the prevailing trends and attitudes toward schooling and migration. In addition, they completed the results of the quantitative analysis, either to support the survey results or to supplement them with any contrary or new aspects mentioned; they also helped us to cross-check information from other sources.

\section{RESULTS}

\section{Differences in education level based on age, gender, ethnicity, and study area}

The level of education is very low among the survey participants: the rate of illiteracy is very high $(69 \%)$, and only $24 \%$ have obtained formal education. The level of schooling held by the survey participants differs significantly between the two study areas, with a higher level of education held by the Senegalese respondents. The differences in formal education are particularly high among the youngest participants (aged 18 to 30). In this age group, $52 \%$ of the Senegalese survey participants have no formal education, compared to $70 \%$ in Mali. Although most of the youngest participants still have no kind of formal schooling, our results show a general trend toward education. Regarding gender, the level of education is significantly lower among women than men in both countries. In the Senegalese study area, we also noticed a significant difference between the two main ethnicities, the Fulani and the Wolof, with a higher level of education found among the Wolof respondents. The survey participants in the Malian study belonged mainly to one ethnicity, the Dogon (Table 1).

\section{The link between people's economic activities and level of education}

Agriculture is the main economic activity of the study participants' families (89\%) and for half of the survey participants themselves. Arable farming makes up the largest proportion of survey participants' activities, with a higher percentage in Mali than in Senegal (52\% vs. $30 \%$ ), where livestock breeding constitutes another important source of income (16\%). Among the Senegalese survey participants, trading in commodities such as car tires or agricultural products is another important source of income (27\%), whereas the Malian respondents are more likely to work as craftsmen or unskilled laborers $(28 \%)$ such as watchmen or housemaids. Nonagricultural activities are more often named by participants surveyed in the capitals.

With regard to education, the analysis shows a significant relationship between the survey participants' level of formal education and their main economic activity $\left(\chi^{2}=95.19, P<\right.$ $0.001)$. The lower their level of education, the more likely respondents are to rely on agriculture as their main source of income (Fig. 2). Agriculture is an economic activity for $58 \%$ of survey participants with no formal education, but only for $18 \%$ of participants with a high level of education. On the contrary, participants with a high level of formal schooling are more likely than those with no formal education to be involved in business or in other sectors such as administration, health, or teaching, which are not directly dependent on climatic or environmental factors. 
Table 1. Respondents' level of formal education by country, age, gender, and ethnicity.

\begin{tabular}{|c|c|c|c|c|c|c|}
\hline \multirow[b]{2}{*}{ Characteristic } & \multirow[b]{2}{*}{ Number of cases } & \multicolumn{3}{|c|}{ Level of education } & \multirow[b]{2}{*}{$\chi^{2}$} & \multirow[b]{2}{*}{$P$} \\
\hline & & No formal & Primary & High level & & \\
\hline \multicolumn{5}{|l|}{ Country: } & 9.358 & 0.009 \\
\hline Mali & 445 & $80 \%$ & $12 \%$ & $7 \%$ & & \\
\hline Senegal & 460 & $73 \%$ & $14 \%$ & $13 \%$ & & \\
\hline \multicolumn{5}{|l|}{ Age: } & 77.86 & $<0.001$ \\
\hline 18 to $30 \mathrm{yr}$ & 301 & $61 \%$ & $19 \%$ & $21 \%$ & & \\
\hline 31 to $50 \mathrm{yr}$ & 362 & $79 \%$ & $14 \%$ & $7 \%$ & & \\
\hline $51 \mathrm{yr}$ and older & 242 & $91 \%$ & $6 \%$ & $3 \%$ & & \\
\hline \multicolumn{5}{|l|}{ Gender: } & 12.02 & 0.002 \\
\hline Male & 532 & $73 \%$ & $14 \%$ & $13 \%$ & & \\
\hline Female & 373 & $81 \%$ & $13 \%$ & $6 \%$ & & \\
\hline \multicolumn{5}{|c|}{ Ethnicity (Senegal only): } & 27.32 & $<0.001$ \\
\hline Fulani & 102 & $93 \%$ & $5 \%$ & $2 \%$ & & \\
\hline Wolof & 354 & $67 \%$ & $17 \%$ & $16 \%$ & & \\
\hline
\end{tabular}

Fig. 2. Main economic activities according to the education level of respondents.

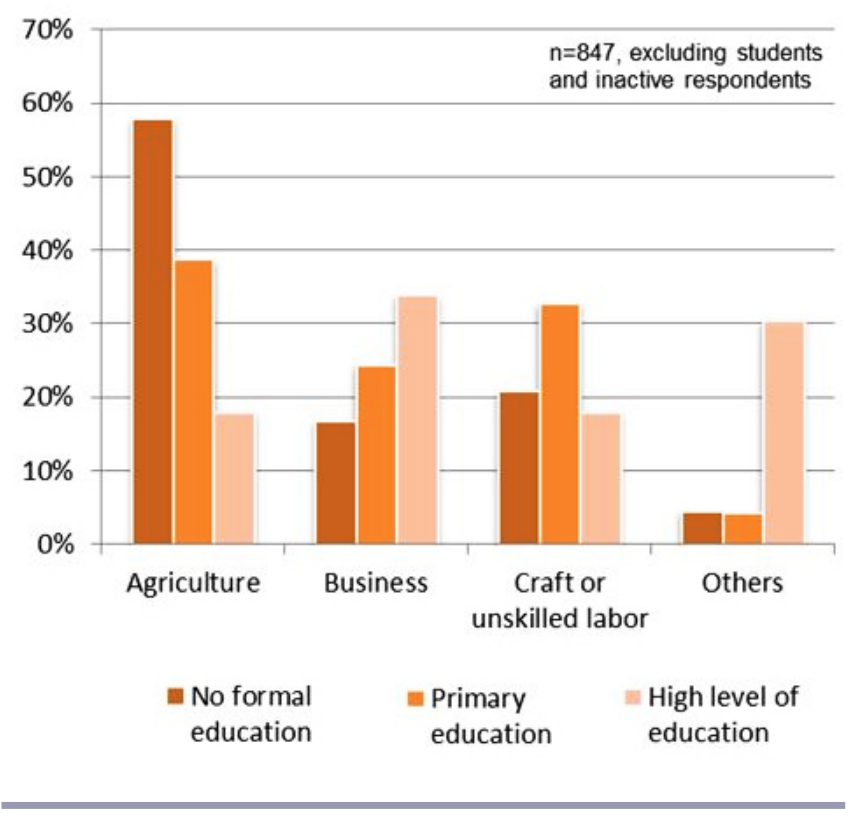

However, not only does the level of education influence the economic activity of the survey participants, but the economic activity of the family also influences the level of education and economic activity of the respondents. The results indicate that survey participants from a family that is involved in agriculture as its main economic activity are far more likely to be involved in an environment-sensitive activity (58\% vs. $9 \%$ ) and less likely to have a formal education than those whose families do not depend on agriculture (22\% vs. $33 \%$ ).
The majority of the active survey participants $(76 \%)$ have more than one source of income: respondents mostly combine arable farming with livestock breeding, small-scale business, or gardening. However, with an increasing level of education and a nonagricultural activity, respondents are more likely to engage in a sole economic activity.

The qualitative interviews support these survey results. Interviewees indicate that children were and still are expected to assist their families in agricultural and domestic work (girls only) instead of attending classes, as shown by the following statement by Aliou, a 34-yr-old man from the Senegalese study area: "It's because of farming that we couldn't go to school. We learned the Koran instead of going to a school because our parents said that their children are destined for farming."

However, the interviews, in line with the survey results, show a trend toward a lower involvement of young people in agricultural activities, which might be linked to an increasing school attendance. The main reasons given for this apart from a higher education are that farming is hard physical work and that the yield of farming has become much lower and more uncertain than it used to be. Young people thus prefer to migrate to the cities to become involved in business and other income-generating activities. People with a high level of education are often attracted by the cities due to better job opportunities. This is illustrated by another statement from Aliou: "Young people who really want to make something of their future have to leave the village to do something other than farming because farming no longer allows you to live well."

\section{Migration and education}

Migration is very common in both study areas: $87 \%$ of the survey participants have personal migration experience, with only small differences between men and women (91\% vs. 
$81 \%$ ). We found no significant relationship between the level of formal education and migration experience. However, the results illustrate that educational attainment influences migration motives. Different levels of education are most significant in connection with the two migration motives "search for money/job opportunities" (initial migration $\chi^{2}=$ 70.40, $P<0.001$; last migration $\chi^{2}=35.44, P<0.001$ ) and "education/vocational training" (initial migration $\chi^{2}=180.31$, $P<0.001$; last migration $\left.\chi^{2}=132.11, P<0.001\right)$ for the survey participant's initial and last migration. Whereas $61 \%$ of survey participants with a high level of education indicate "education and/or vocational training" as one of their main objectives for initial migration, this applies only to $9 \%$ of participants with no formal education or a primary education. Most respondents with no formal education or only primary education (each $64 \%$ ) give "search for money/job opportunities" as one of their main objectives for initial migration, whereas the more highly educated express far less agreement with this motive (17\%). This is hardly surprising because scholars, particularly for secondary education, often have to move to bigger villages or cities to attend classes.

More surprising is that the differences between the migration motives and the level of education also apply for people's last migration (Fig. 3). Whereas $45 \%$ of survey participants with a high level of education state "education and/or vocational training" as one of their main objectives for initial migration, it plays only a minor role for those with no formal education or a primary education. The "search for money and job opportunities" is an important motive for the last migration of survey participants, but it plays a bigger role for participants with no formal education or a primary education.

With regard to gender, hardly any women confirm education or vocational training as a motive for initial migration compared to men (5\% vs. $19 \%$ ). Women's main motives for their first migration is, as for men, the "search for money/job opportunities" (45\% vs. 67\%). However, they also mention other motives that are hardly mentioned by men: "family reasons" (36\% vs. $5 \%)$ and visits (19\% vs. $7 \%)$. A similar relationship regarding the motives of men and women applies also for people's last migration. With respect to its role in their migration, men state education more often than do women as one main motive for their first (19\% vs. $5 \%$ ) and last migration (10\% vs. $3 \%)$.

Our findings reveal that migration can be one of several coping strategies to compensate for climate variability and environmental changes. The survey results illustrate that with an increasing level of education, people more often confirm that their families compensate for a bad harvest or bad conditions for livestock breeding by increasing money transfers from migrant family members (high education: $70 \%$ vs. $47 \%$ for participants with no formal education; $\chi^{2}=17.04$, $P<0.001)$. Another strategy is to increase the number of migrants in the family; this is reported slightly more frequently by participants with primary-level education or no formal education than by the better educated $(29 \%$ and $36 \%$ vs. $19 \%$; $\left.\chi^{2}=6.52, P<0.05\right)$. We found no significant relationship between the level of education and other coping strategies such as borrowing money from someone or taking out a bank loan, selling livestock, or engaging in small-scale business.

Fig. 3. Main motives behind people's last migration, depending on their education level.

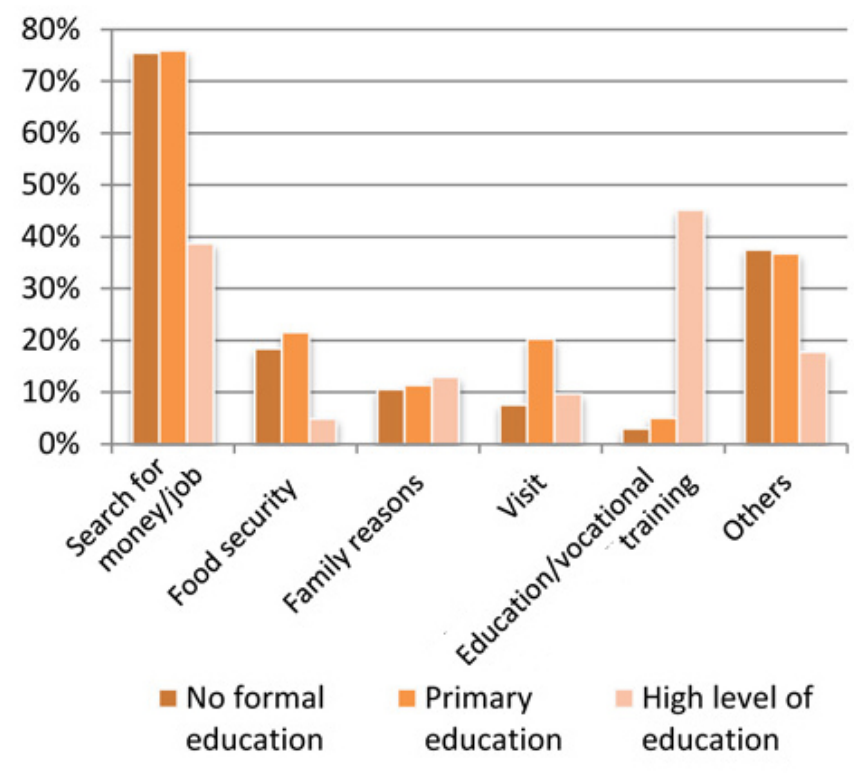

The qualitative interviews illustrate that, particularly in the past but also today, young people refuse to go to school, or leave school earlier to migrate in search of a job to support their families by sending money, food, or other goods. The following statement by Abdou, a 60-yr-old man from Senegal, confirms migration as a common strategy to compensate for bad harvests: "Every family is divided in two groups: one group stays in the village for farming (...) and one group migrates to the cities to work and support the family. If the yields are not good, those in the cities are obliged to support the family by sending money to the village."

However, the qualitative analysis indicates that migration patterns among the young people change with improved opportunities for schooling: in some villages today, fewer young people are leaving in search of job opportunities than in the past because they attend school more often and for a longer period instead. This is confirmed by a quote from Binta, a 22-yr-old woman in Mali: "If you have no education, if you do not go to school and you do nothing, you have to leave to search for money, like I did." 
Interviewees and survey participants assess migration in a positive light, not least because it is an important means of supporting their family's livelihood: $86 \%$ of survey participants would recommend migration to other family members, although $27 \%$ would qualify this in terms of destination. We found no significant relationship between the level of education and attitudes toward migration. However, some interviewees consider migration itself as "a school of life," which is confirmed by the statement by Oumu, a 22-yrold woman in Mali: "When I left the village, I got to know many people, I learned how to live, that's to say I gathered a lot of experience and was able to derive personal benefit from it. I also learned a language, Bambara."

\section{DISCUSSION}

The results indicate a general trend toward formal education in both study areas, which can be confirmed by current literature on schooling enrolment (UNESCO 2012). However, the level of education is still low, with $61 \%$ of the youngest participants (aged 18 to $30 \mathrm{yr}$ ) receiving no formal schooling. Female participants generally tend to be educated to a lower level than men. With regard to ethnicities in the Senegalese study area, our results reveal that formal education among the Fulani interviewees is less common than among the Wolof. This can be explained by the traditionally nomadic culture of the Fulani, which makes it difficult to enrol their children in schools.

Most families in our study regions depend on agricultural activities as their main source of income and are thus presumed to be vulnerable to environmental change and high climate variability. This affects not only education but also the decision to migrate.

\section{Formal education reduces vulnerability to environmental changes}

The results illustrate that the probability of young people not being involved in agriculture as their main economic activity rises with their level of education. Thus, the hypothesis that people with a high level of formal education are less vulnerable to environmental changes is confirmed because people with a formal education, and particularly the better educated, are less dependent on climate-sensitive economic activities. But in turn, the economic activity of the family also influences the level of formal education held by survey participants.

Quantitative and qualitative results show that many youths do not seem to see their future in agriculture, which is highly dependent on unpredictable, highly variable, or scarce rainfall and decreasing soil fertility. Although $89 \%$ of the survey participants' families in both study areas rely heavily on agricultural activity, the percentage is much lower for the participants themselves. According to the interviews, this is due to a better schooling infrastructure and also to decreasing yields. Instead, they aspire to alternative job opportunities in the cities and to a life that seems more likely to be better with a (better) education.

Moreover, our results show that people from families that do not obtain their livelihood from agricultural activity are more likely to exhibit a high level of education and do not depend on agriculture themselves. Families relying on agriculture as a main source of income often prefer their children to support them in farming or in domestic work, instead of attending classes. This is also supported by Hadley (2012), who illustrated that in sub-Saharan Africa, access to education is also subject to seasonal dimensions: In Senegal, for example, seasonal absenteeism from school is common during planting and harvesting seasons, when children are required to care for livestock and mind younger siblings to allow adults to undertake income-generating activities. In addition, our interviews indicate that young boys and girls from such families often leave school early to migrate in search of money and job opportunities to support the family in the village. Agriculture as a main economic activity of the family thus may reduce the likelihood of achieving a higher education level. However, whether or not children go to school, and for how long, depends also on many other aspects such as the distance or transport to school, the financial situation of their parents, and their parents' attitudes toward education (Fentiman et al. 1999, Hadley 2012).

Although some studies oppose the link between formal education and people's economic activity (Ndiaye 1998, Weyer 2011), our results reveal that the higher the level of education, the less dependent survey participants are on an environment-sensitive economic activity. Respondents with no formal education or a primary education depend more often on agricultural activities and are thus more vulnerable to natural hazards. They are mainly engaged in several economic activities, often related to migration, to spread the families' risk related to environmental stress. Several studies emphasize that in the Sahel, women make up 50-80\% of the agricultural labor force. They rely on land, soil conditions, and regular rainfall for agriculture, which makes them particularly vulnerable to environmental changes (Denton 2002, UNEP 2011). In this context, more detailed empirical research is required to examine whether and how women are more vulnerable due to their lower education attainment.

\section{Migration motives differ with level of education}

Current debates on environmentally induced migration argue in favor of a context-specific analysis of the determining factors of migration that takes account of social, cultural, economic, and political aspects that interact with environmental factors (Black 2001, Castles 2002, Piguet et al. 2011). Our results show no significant relationship between people's migration experience or propensity for migration and their level of education, for men and for women. Therefore, our hypothesis that a higher level of education increases the 
propensity for migration and hence its probability for both men and women has to be rejected. This result contradicts the statement in the literature that educational attainment enhances the mobility of women (Adepoju 1995b, 2002, de Haas 2008).

However, our results do illustrate that education is one of several important social aspects influencing a migration decision in fragile environments. In the West African Sahel, circular migration is an important livelihood strategy to diversify income and to reduce the household's vulnerability to environmental stress through remittances (Adepoju 1995b, Black 2001), which is confirmed by the qualitative interviews. However, this seems to apply only to people with no formal education or with primary education, who give the search for job or money-earning opportunities as the main objective of their first and last migration. On the contrary, the better educated survey participants (at least to secondary level) mainly migrate in pursuit of education or vocational training. Female survey participants barely mention education as a motive for their migration, which might be explained by their lower education level.

The qualitative interviews illustrate that respondents have to leave school early to migrate: females primarily to earn their dowry or to assist relatives, and males in search of a job to support their family. This is particularly the case for the first born, who has a cultural obligation to support the parents. Migration is specifically reported in the literature as a constraint for education in the case of low-skilled migration (de Haas 2008) and for girls (Fentiman et al. 1999). However, the survey results illustrate that the well-educated respondents tend to be in a better position to increase the money transfers from migration to their families than are people with no formal education or primary education. Remittances from family members in migration are often invested in the education of other family members and can thus turn education into a strategy to improve the lives of the family members (Adepoju 1995b). Moreover, many migrants consider migration itself as an education that opens up possibilities of discovering and learning new things. Overall, these different findings are very much in keeping with the basic assumptions of the sustainable livelihoods approach and the social vulnerability concept described above, which emphasize the role of education as an important asset when it comes to improving the quality of life and adaptive capacity.

\section{CONCLUSION}

We examined the role of formal education in environmentally induced migration using the example of two Sahelian regions in Mali and Senegal. These regions are presumed to be affected negatively by climate change and by environmental changes such as land degradation, which place pressure on the majority of inhabitants, who mainly have a low level of education and rely heavily on agriculture to sustain their livelihoods.
In summary, the results confirm that people with a high formal education are less vulnerable to environmental stress because they are less dependent on environment-sensitive economic activities. Interestingly, the education level has no significant effect on the migration experience as such. However, motives for migration differ clearly depending on people's level of education. This suggests that labor migration appears to be a strategy to reduce vulnerability to environmental changes mainly for people with no formal education or with primary education, whereas the better educated primarily migrate for education or vocational training.

Based on our empirical findings, people's capacity to adapt to natural hazards is clearly influenced by their educational status: education increases their options so that they are no longer entirely at the mercy of a fragile environment. We conclude that policies designed to promote and facilitate formal education, particularly for those dependent on agriculture to sustain their livelihoods, first and foremost reduce the vulnerability of the population in Sahelian regions and other areas negatively affected by climate and environmental changes. Once they have migrated, the better educated people do not usually return to their rural places of origin. For those who want to leave and aspire to a better life in a nonagricultural activity, a formal education is a critical requisite. For those who want to stay, it is essential to create perspectives by embedding policies for the enhancement of formal education in comprehensive strategies for sustainable regional development.

Responses to this article can be read online at: http://www.ecologyandsociety.org/issues/responses. php/5830

\section{Acknowledgments:}

We thank subject editor William P. Butz and the editors of Ecology and Society as well as two anonymous reviewers for their constructive comments and suggestions. We are also grateful for the valuable comments of our colleague Georg Sunderer and the members of the micle project. Special thanks to the German Federal Ministry for Education and Research $(B M B F)$ for funding our research.

\section{LITERATURE CITED}

Adepoju, A. 1995a. Emigration dynamics in sub-Saharan Africa. International Migration 33(3-4):313-390.

Adepoju, A. 1995b. Migration in Africa: an overview. Pages 87-108 in J. Baker and T. A. Aina, editors. The migration experience in Africa. Nordiska Afrikainstitutet, Uppsala, Sweden. 
Adepoju, A. 2002. Fostering free movement of persons in West Africa: achievements, constraints, and prospects for intraregional migration. International Migration 40(2):3-28. http://dx.doi.org/10.1111/1468-2435.00188

Adger, W. N., N. Brooks, G. Bentham, M. Agnew, and S. Eriksen. 2004. New indicators of vulnerability and adaptive capacity. Technical Report 7. Tyndall Centre for Climate Change Research, University of East Anglia, Norwich, UK. [online] URL: http://www.tyndall.ac.uk/sites/default/files/ Adger\%20W.\%20N\%20.,\%20Brooks, \%20N.\%20,\%20Kelly, $\% 20$ M.,\%20Bentham $\%$ 20S.\%20and\%20Eriksen,\%20S.\%20(2004)\%20New\% 20indicators $\% 20$ of $\% 20$ vulnerability $\% 20$ and $\% 20$ adaptive $\%$ 20capacity\%20(tr7).pdf.

ANSD (Agence Nationale de la Statistique et de la Démographie). 2006. RGPH III - Rapport national de présentation des résultats définitifs. Résultats définitifs $d u$ troisième recensement général de la population et de l'habitat, 2002. ANSD, Dakar, Senegal.

Black, R. 2001. Environmental refugees: myth or reality? New Issues in Refugee Research Working Paper 34. UNHCR, Geneva, Switzerland. [online] URL: http://www.unhcr. org/3ae6a0d00.html.

Black, R., W. N. Adger, N. W. Arnell, S. Dercon, A. Geddes, and D. S. G. Thomas. 2011. The effect of environmental change on human migration. Global Environmental Change 21(S1):S3-S11. http://dx.doi.org/10.1016/j.gloenvcha.2011.10.001

Bocquier, P., and S. Diarra. 1999. Migration internes et internationales. Pages 63-74 in P. Bocquier and T. Diarra, editors. Population et société au Mali. L'Harmattan, Paris, France.

Carney, D., editor. 1998. Sustainable rural livelihoods: What contribution can we make? Department for International Development (DFID), London, UK.

Castles, S. 2002. Environmental change and forced migration: making sense of the debate. New Issues in Refugee Research Working Paper 70. UNHCR, Geneva, Switzerland. [online] URL: http://www.unhcr.org/3de344fd9.html.

Chambers, R., and G. R. Conway. 1992. Sustainable rural livelihoods: a practical concept for the 21st century. IDS Discussion Paper 296. Institute of Development Studies, Brighton, UK. [online] URL: http://www.ids.ac.uk/files/ Dp296.pdf.

Cline, W. R. 2007. Global warming and agriculture: impact estimates by country. Peter G. Peterson Institute for International Economics, Washington, D.C., USA.

Cutter, S. L., B. J. Boruff, and W. L. Shirley. 2003. Social vulnerability to environmental hazards. Social Science
Quarterly 84(2):242-261. http://dx.doi.org/10.1111/1540-6237.8402002

De Haas, H. 2008. Migration and development: a theoretical perspective. International Migration Institute Working Paper 9. International Migration Institute, University of Oxford, Oxford, UK.

Denton, F. 2002. Climate change vulnerability, impacts, and adaptation: Why does gender matter? Gender and Development 10(2):10-20.

Diekmann, A. 2005. Empirische Sozialforschung. Grundlagen, Methoden, Anwendungen. Thirteenth edition. Rowohlt, Reinbek/Hamburg, Germany.

Doevenspeck, M. 2011. The thin line between choice and flight: environment and migration in rural Benin. International Migration 49(S1):e50-e68. http://dx.doi.org/10.1111/ j.1468-2435.2010.00632.x

Fentiman, A., A. Hall, and D. Bundy. 1999. School enrolment patterns in rural Ghana: a comparative study of the impact of location, gender, age and heath on children's access to basic schooling. Comparative Education 35(3):331-349. http://dx. doi.org/10.1080/03050069927865

Findley, S.E. 1994. Does drought increase migration? A study of migration from rural Mali during the 1983-1985 drought. International Migration Review 28(3):539-553. http://dx.doi. org/10.2307/2546820

Hadley, S. 2012. Seasonality and access to education in subSaharan Africa. Pages: 265-277 in S. Devereux, R. SabatesWheeler, and R. Longhurst, editors. Seasonality, rural livelihoods and development. Earthscan, London, UK.

Hummel, D., M. Doevenspeck, and C. Samimi, editors. 2012. Climate change, environment and migration in the Sahel: selected issues with a focus on Senegal and Mali. Micle Working Paper 1. ISOE, Frankfurt, Germany. [online] URL: http://www.micle-project.net/fileadmin/redaktion/Download/ micle-wp1-2012-en.pdf.

IPCC (Intergovernmental Panel on Climate Change). 2007. Climate change 2007: impacts, adaptation and vulnerability. Contribution of Working Group II to the Fourth Assessment Report of the Intergovernmental Panel on Climate Change. Cambridge University Press, Cambridge, UK.

K.C., S. 2013. Community vulnerability to floods and landslides in Nepal. Ecology and Society 18(1): 8. http://dx. doi.org/10.5751/ES-05095-180108

Kelly, P. M., and W. N. Adger. 2000. Theory and practice in assessing vulnerability to climate change and facilitating adaptation. Climatic Change 47(4):325-352. http://dx.doi. org/10.1023/A:1005627828199 
Lutz, W., and S. K.C. 2011. Global human capital: integrating education and population. Science 333(6042):587-592. http:// dx.doi.org/10.1126/science.1206964

Mayring, P. 2007. Qualitative Inhaltsanalyse. Grundlagen und Techniken. Ninth edition. Beltz, Weinheim, Germany.

Mbow, C., O. Merz, A. Diouf, K. Rasmussen, and A. Reenberg. 2008. The history of environmental change and adaptation in eastern Saloum-Senegal-driving forces and perceptions. Global and Planetary Change 64(3-4):210-221. http://dx.doi.org/10.1016/j.gloplacha.2008.09.008

McLeman, R. A., and L. M. Hunter. 2010. Migration in the context of vulnerability and adaptation to climate change: insights from analogues. WIREs Climate Change 1 (3):450-461. http://dx.doi.org/10.1002/wcc.51

McLeman, R., and B. Smit. 2006. Migration as an adaptation to climate change. Climatic Change 76(1-2):31-53. http://dx. doi.org/10.1007/s10584-005-9000-7

Mertz, O., C. Mbow, J. Østergaard Nielsen, A. Maiga, D. Diallo, A. Reenberg, A. Diouf, B. Barbier, I. Bouzou Moussa, M. Zorom, I. Ouattara, and D. Dabi. 2010. Climate factors play a limited role for past adaptation strategies in West Africa. Ecology and Society 15(4): 25. [online] URL: http://www. ecologyandsociety.org/vol15/iss4/art25.

Ndiaye, M. 1998. L'Ethique Ceddo et la société d'accaparement. Tome 2: Les modou modou. Presse Universitaire, Dakar, Senegal.

Piguet, E., A. Pécoud, and P. de Guchteneire, editors. 2011. Migration and climate change. Cambridge University Press, Cambridge, UK.

Rademacher-Schulz, C., and E. S. Mahama. 2012. Rainfall, food security and human mobility. Case study: Ghana. Where the Rain Falls Project Report 3. United Nations University Institute for Environment and Human Security (UNU-EHS), Bonn, Germany. [online] URL: http://www.ehs.unu.edu/file/ get/10564.

Renaud, F. G., O. Dun, K. Warner, and J. Bogardi. 2011. A decision framework for environmentally induced migration. International Migration 49(S1):e5-e29. http://dx.doi.org/10.1111/ j.1468-2435.2010.00678.x

Roth, E., and K. Heidenreich. 1995. Sozialwissenschaftliche Methoden: Lehr- und Handbuch für Forschung und Praxis. Fourth edition. Oldenbourg, Munich, Germany.

Samimi, C., and M. Brandt. 2012. Environment and migration in the Sahel. Pages 20-36 in D. Hummel, M. Doevenspeck, and C. Samimi, editors. Climate change, environment and migration in the Sahel: selected issues with a focus on Senegal and Mali. Micle Working Paper 1. ISOE, Frankfurt, Germany.
Scheffran, J., E. Marmer, and P. Sow. 2012. Migration as a contribution to resilience and innovation in climate adaptation: social networks and co-development in northwest Africa. Applied Geography 33:119-127. http://dx.doi.org/10.1016/j. apgeog.2011.10.002

Striessnig, E., W. Lutz, and A. G. Patt. 2013. Effects of educational attainment on climate risk vulnerability. Ecology and Society 18(1): 16. http://dx.doi.org/10.5751/ES-05252-180116

Tacoli, C. 2011a. Not only climate change: mobility, vulnerability and socio-economic transformations in environmentally fragile areas of Bolivia, Senegal and Tanzania. Human Settlements Working Paper Series. RuralUrban Interactions and Livelihood Strategies 28. IIED, London, UK. [online] URL: http://pubs.iied.org/pdfs/10590IIED. pdf.

Tacoli, C. 2011b. Migration and global environmental change. CR2: The links between environmental change and migration: a livelihoods approach. Foresight Project, Government Office for Science, London, UK. [online] URL: http://www.bis.gov.uk/assets/foresight/docs/migration/case-studyreviews/11-1191-cr2-links-environmental-change-and-migrationlivelihoods.pdf.

UNEP (United Nations Environment Programme). 2011. Livelihood security: climate change, migration and conflict in the Sahel. UNEP, Geneva, Switzerland. [online] URL: http://www.unep.org/pdf/UNEP_Sahel_EN.pdf.

UNESCO. 2012. Adult and youth literacy. UIS Fact Sheet 2. UNESCO Institute for Statistics, Paris, France. [online] URL: http://www.uis.unesco.org/FactSheets/Documents/ss20-literacyday-2012-en-v3.pdf.

Urry, J. 1999. Mobile cultures. Department of Sociology, Lancaster University, Lancaster, UK.

Wamsler, C., E. Brink, and O. Rantala. 2012. Climate change, adaptation, and formal education: the role of schooling for increasing societies' adaptive capacities in El Salvador and Brazil. Ecology and Society 17(2): 2. http://dx.doi. org/10.5751/ES-04645-170202

Weyer, F. 2011. Diversification of educational provision and school-to-work transitions in rural Mali: analysing a reconfiguration of inequalities in light of justice theories. International Journal of Educational Development 31 (5):573-575. http://dx.doi.org/10.1016/j.ijedudev.2011.02.007 